\title{
Lived Experience, Historical Consciousness and Narrative: A Combinatory Aesthetics Ethic
}

\author{
David Pendery ${ }^{1}$ \\ ${ }^{1}$ Department of Applied Foreign Languages, National Taipei University of Business, Taipei County, Taiwan \\ Correspondence: David Pendery, Associate Professor, Department of Applied Foreign Languages, National \\ Taipei University of Business, P.O. Box 142 Yonghe, Taipei County, 23499, Taiwan.
}

Received: March 10, 2016

Accepted: April 10, 2016

Online Published: September 12, 2016

doi:10.20849/ajsss.v1i2.60

URL: http://dx.doi.org/10.20849/ajsss.v1i2.60

\begin{abstract}
In this paper I introduce the conception of an "aesthetics ethic" conditioning historical consciousness and writing. The aesthetic ethic is a concept that touches on epistemological, cognitive, aesthetic, experiential, linguistic and ontological qualities that are very much in accord in both historiography and historical novelization. By way of this synthesis, I posit a strong, binding amalgamation that links these two genres. There are a number of transacting ideas and methodological approaches in this work. The focus in this paper is the aesthetic ethic, proper. The aesthetic ethic is a dynamic, densely deliberative field comprising individual and community historical experience, embedded within profoundly aesthetic and conscious contexts, in which history is first lived, and historical writing by historians and historical novelists is then composed. The aesthetics ethic constitutes an environmentality studded with manifold elements of subjectivity, objectivity and intersubjectivity; imagination and artfulness; intentionality and actualization; enunciation and circumscription; reference and contrivance; experience and conjecture; intellection and apperception; contingency and modality. The aesthetics ethic will, I hope, prove to be a useful map revealing details about how historians and historical novelists perceive (one of the source meanings of aesthetic) common facets of historical consciousness amidst a true kinship (one of the source meanings of ethic) of overlapping interests, methods and aims. By way of this overall amalgamation, the synthesis I have referred to is effected, linking the writings and interpretations of historians and historical novelists in important ways. I refer to a number of important analysts in this study, perhaps most importantly John Dewey, Hayden White and Frank Ankersmit. As well, an important phase of analysis is my study of Daniel Wickberg's theory of "histories of sensibilities".
\end{abstract}

Keywords: history, historical consciousness, historians, historical novelists, historiography, historical novelization, aesthetics, sensibilities

The most elaborate philosophic or scientific inquiry and the most ambitious industrial or political enterprise has, when its different ingredients constitute an integral experience, esthetic quality. For then its varied parts are linked to one another, and do not merely succeed one another. And the parts through the experienced linkage move toward a consummation and close, not merely to cessation in time. This consummation, moreover, does not wait in consciousness for the whole undertaking to be finished. It is anticipated throughout and is recurrently savored with special intensity.

John Dewey, Art as Experience

\section{Introduction}

IN THIS PAPER I will introduce the conception of an "aesthetics ethic" conditioning historical consciousness and composition. The aesthetics ethic constitutes an environmentality studded with manifold elements of subjectivity, objectivity and intersubjectivity; imagination and artfulness; intentionality and actualization; enunciation and circumscription; reference and contrivance; experience and conjecture; intellection and apperception; contingency and modality. It is a dynamic, densely deliberative field and dappled experiential and communicative ground comprising individual and community historical experience embedded within profoundly aesthetic and conscious contexts, in which history is first lived, and then historical writing of two unique but related varieties of historical writing is constructed: that of historians and historical novelists. 
The aesthetics ethic will, I hope, prove to be a thoroughgoing map revealing details about how historians and historical novelists perceive (one of the source meanings of aesthetic) common facets of historical consciousness amidst a true kinship (one of the source meanings of ethic) of overlapping interests, methods and aims. The audiences of these writers return the favor of this visionary, historically-attuned accord, and the sum of these attitudes, perceptions, assumptions and beliefs synchronize in fruitful ways. By way of this synthesis, I will, in a turn perhaps reminiscent of the work of Hayden White, posit a strong, binding amalgamation (I will as often as not refer to historians and historical novelists as a single group of "historical writers")-and this is in fact an essential motivation of this essay. I hope that we will see the aesthetics ethic as the threshold where historical experience and historical narrative muster, transgress, interlard and ultimately effectuate a transactive blend of interpretation and meaning. This idea is distilled and adumbrated in the thoughts of Robert Scholes and Robert Kellogg, who wrote that "Meaning, in a work of narrative art, is a function of the relationship between two worlds: the fictional world created by the author and the 'real' world, the apprehendable universe". (Note 1)

This aesthetics ethic framework, I think, accords with the thoughts of historian Johan Huizinga (1872-1945), who wrote that historical sense is a reticular but methodical synthesis that "proves anew its close connection with the forms of thought of ordinary human life, which also would be impossible without general categories into which intelligence organizes phenomena". (Note 2) Huizinga added that "by reason of its natural bent historical sense always inclines toward the particular, the graphic, the concrete, the unique, the individual". (Note 3) Huizinga's conceptions here fit with his research methodology, which held that "no knowledge of the particular is possible without its being understood within a general frame" and, yet more poetically, "Every historical fact opens immediately into eternity". (Note 4) Huizinga's thoughts seem to rehearse those of my model, with its "general" philosophical/phenomenological frame of historical consciousness, experience and understanding, alongside larger moral and ethical aims and outcomes in human communities; conditioned by "particular" aesthetic and narrative details, emerging out of conscious and compositional processes and structures.

\section{The Aesthetics Ethic: Aesthetic Contours in Lived Experience}

HISTORICAL EXPERIENCE AND REPRESENTATION are the veritable mortise and tenon of my examination. As Frank Ankersmit once wrote, "representation is the birthplace of meaning - and whoever is interested in the nature of meaning can do little better than to closely investigate representation". (Note 5) Representation and meaning-conceptions that cut to the heart of the crossroads of lived experience, narrated history and historicized narrative, which I will examine by way of the aesthetics ethic.

I turn here to two facets of historical representation, and link the conceptions to the above ideas. We might say that historical writers are in one sense representatives of their communities, who by way of their representations speak for those communities, interpreting and expounding lived experience in all of its epistemological, ontological, moral/ethical, aesthetic and referential plenitude. As community representatives historical writers "are socioculturally mediated, that is, they are fundamentally connected to the cultural and social background of an agent, to a group practice, and, not least, to an intersubjective situation". (Note 6) In terms of this social background, group practice, and intersubjectivity, these writers are immersed in transacting Habermasian "situation definitions" in the lifeworld, with human communication and interaction hinging on validity claims through which consent is negotiated by way of relationships among the objective/purposive, normative/pragmatic and subjective/individual. (Note 7)

In terms of representation, some will say that the two genres being considered here are wholly different, with historians indeed representing, or re-representing, the past, and novelists doing no such thing - in fact they do something like misrepresent the past in their narratives (they are liars). I take the opposing view, and posit at the highest level that the representational value and general validity of representation-this species, this class of communicative action - is in sum equal across the two genres. If to offer a slightly heated illustration, to claim they are wholly distinctive would be like claiming that peoples with varying tints and hues of skin colour are substantively, essentially different. There are differences on the outside of course, and the cultures of these different "peoples" also evince their own unique qualities - but their lifeblood, their DNA, their very existence and interaction, functioning and outcomes, are of the same ilk. A related point is how some would claim that the assumptions, interpolations and interpretations of historians are valid, while those of historical novelists are not. But in the same way as above, this is a difference of degree, not of kind. To illustrate the common interpretive ground beneath historical novels and historiography, I select a few examples from Daniel Jonah Goldberg's Hitler's Willing Executioners. In the text we are given interpretive guidance and license by way of diction such as: "Even if the interpretation put forward here of the Einsatzgruppen's exact order is wrong ... the order was still genocidal;" "Although it is not known for sure, it is most unlikely that Hitler decided to annihilate Soviet Jewry without at the same time deciding...;" "Our knowledge of police battalion activities during the war is 
fragmentary and partial. ... An overview ... however, can be constructed;" "such genocidal opportunities were available to the men of many police battalions, and it is probable - though it is not known...;" "The men of these nine battalions form a sample sufficient to generalize...," "Another member of the battalion ... explains why they (presumably also Police Battalion 101 member Erwin Grafmann) did not have any moral qualms about what they were doing". (Note 8) Even if, it is not known for sure, most unlikely, knowledge fragmentary and partial, constructed overviews, it is probable, sufficient to generalize, presumably-such interpretive authorization and modal methodology looks like an ideal ground on which to construct historical novelization with its concomitant re-imagining of historical incident-and yet it is also part and parcel of the empirical historiographic enterprise. Observe here another illuminating example from Goldhagen. Examining life in one concentration camp that had an equal number of male and female guards who got along together very well — to the point of forming love relationships - Goldhagen darkly frames several questions: "The Germans made love in barracks next to enormous privation and incessant cruelty. What did they talk about when their heads rested quietly on their pillows, when they were smoking their cigarettes in those relaxing moments after their physical needs had been met? Did one relate to another accounts of a particularly amusing beating that she or he had administered or observed, of the rush of power that engulfed her when the righteous adrenaline of Jew-beating caused her body to pulse with energy?" (Note 9) Indeed, we wonder, what would they have thought and felt and talked about.... Goldhagen does not attempt to reconstruct these dialogs, but some historians would, and to do this they would of course refer to historical source materials - letters, diaries, wills, albums, receipts, and the like - exactly as a historical novelist would. As Gore Vidal wrote of his historical novel Lincoln, which was written based on extensive research into authentic historical source materials: "All of the principal characters really existed, and they said and did pretty much what I have them saying and doing". (Note 10) Reconstruction like this, interpreting and answering questions about historical experience and outcomes like these, is an enterprise in which historians and historical novelists are "presented with different but overlapping opportunities," (Note 11) and we find that these varieties of historical writing become modes in a single transactive paradigm. (Note 12)

To delve deeper into the aesthetic contours that rib the ethical model I am constructing, Historian Jerzy Topolski has written that "It is not logic but imagination that generates more or less concretized mental images constituting a background onto which the historian, 'playing' with basic information, imposes some content, occasionally modifying the ground (an effect of idealization) in one way or another". (Note 13) Though Topolski specifically refers to the historian, let everyone be his own historian, and let Topolski's ideas be an introduction into the idea of aesthetics as an organic constituent of lived experience, with our perception (and associated imagination) virtually the essence of narrative/aesthetic consciousness, which in turn constitutes the veritable quiddity of the lived-apprehended-interpreted-incorporated-participatory-synergetic life world —our history, the story and record of all we are. What we are describing is an expansive view, a view onto human ontology, taking in worlds of experience, action, perception, apperception and communication, coursing reciprocally from interior subjectivity, to exterior objectivity, to communal intersubjectivity and back again. To support this view, in the following I will primarily turn to one thinker, who himself takes such an encompassing view of life and letters: the great John Dewey.

John Dewey's analyses in Art as Experience, with their views on the aesthetic bases and contours of lived experience, human action, creativity and communication-all environmentally conditioned, recursively employed, emotively expressed, aesthetically germinated, adaptively accorded and temporally consummated - is where I shall begin. One of Dewey's principal ideas is a transactive doing and undergoing, experiences caparisoned with manifold aesthetic intricacies. For Dewey, subjectivity, objectivity and intersubjectivity necessitate and engender an initial aesthetic impulse that yields an artful "doing" by agents (in our analysis, historical writers) that is in turn "undergone" by their peers (fellow writers, and readers). This is a combinatory effort of creation and interpretation, aesthetic to the core, welding subject and object into a dynamic quicksilver: "The uniquely distinguishing feature of esthetic experience is exactly the fact that no such distinction of self and object exists in it, since it is esthetic in the degree in which organism and environment cooperate to institute an experience in which the two are so fully integrated that each disappears". (Note 14) As to some of the particulars of this aesthetics ethic, Dewey goes on that "As an organism increases in complexity, the rhythms of struggle and consummation in its relation to its environment are varied and prolonged, and they come to include within themselves an endless variety of sub-rhythms. The designs of living are widened and enriched. Fulfillment is more massive and more subtly shaded." (Note 15) To sum up, Dewey's aesthetic world and experience become:

an everlastingly renewed process of acting upon the environment and being acted upon by it, together with institution of relations between what is done and what is undergone. Hence experience is necessarily cumulative 
and its subject matter gains expressiveness because of cumulative continuity. ... Things and events experienced pass and are gone. But something of their meaning and value is retained as an integral part of the self. (Note 16)

This very Husserlian, time-conscious field is a fertile expanse that traverses the fictional and non-fictional, the performed and eventuated, the imagined and experienced. Such aesthetic conditioning within lived experience is an astonishingly vital, wholly ecological, hyper-responsive, intricately temporal and blazingly imaginative cross-fertilization of community and individual historical consciousness, commitment and communication, an eyes-wide-open trek across potential toward consummation. For Dewey, aesthetics in lived experience is nothing less than a "unique transcript of the energy of the things of the world" by way of which we "reach to the roots of the esthetic in experience" and then, coming out on the other side as it were, achieve "a transformation of interaction into participation and communication". (Note 17) Linking these ideas up to historical apprehension and narrative, Dewey continues that aesthetics in lived experience are "a manifestation, a record and celebration of the life of a civilization," and also "the means for entering sympathetically into the deepest elements of remote and foreign civilizations". (Note 18) Dewey's reference here to "a manifestation, a record ... of the life of a civilization" and our aesthetically-conditioned ability and aim to "enter sympathetically into the deepest elements of remote and foreign civilizations" remind us that, as the ground of all historicity, the aesthetics ethic, is a veritable window opening onto the historical experience of peoples and ages past - and from there the source of historical writing.

These varied ideas can be applied to my aesthetics ethic, a framework comprising an amalgamation of human awareness, existence, and narrative enterprise, insinuating itself into a truly encompassing historical view and consciousness, steeped in intersubjectivity and phenomenological intentionality, with an essential aesthetic thrust emerging from human consciousness and entering into the flourishing communicative endeavors of historiography and historical fiction. We live, perceive, enact, historicize, commune, narrate, know, understand, engender, characterize and develop within this environment, with all of this activity forming a mighty current that sweeps us along in genuinely aesthetic, narrative lived experience toward the denouement of narrated history - to repeat, the story and record of all we are.

\section{The Aesthetics Ethic: A Social Ethic}

AS ALREADY INDICATED, the aesthetics ethic that I am proposing is a deeply social construct, with aesthetic contours that contribute to ethical and moral outcomes in human communities through communicative action that is at once subjective/visionary, intersubjective/correlative, and objective/material (all terms which, I should add, are inherently transactive and textual). It is a fertile world of human collaboration, creation and concert, a richly collective, correspondent and consensual milieu that becomes a wider aesthetic field encompassing areas of society, community, convention, learning, expectation, composition and ideology - all central intellectual, emotional, conscious, cognizant, community and in sum ethical elements of the aesthetics ethic.

As introduced above, Jerzy Topolski discusses how the historian's aim is to forge an imaginative and cognitive accord with readers that "yields to the pressure of conventions functioning in society or, more precisely, in the community of historians. ... There is often a plurality of conventions characteristic of different schools of historiography, related to particular political, religious, and ideological views". (Note 19) William Cronon (Frederick Jackson Turner Professor of History, Geography, and Environmental Studies, University of Wisconsin Madison) reminds us once again of the historian's situation and role in this widened communal field and medium of lived experience when he writes that "We historians write as members of communities, and we cannot help but take those communities into account as we do our work". (Note 20)

As I have noted, audiences reciprocate in this environment, and are "prepared to accord the historian the exorbitant right to know other minds". (Note 21) Karsten R. Stueber (professor and chair in philosophy, College of the Holy Cross) adds that "historians ... appeal to large-scale and supra-individual facts such as general cultural habits prevalent at a time, or structures and norms of various institutions". (Note 22) Stueber also writes, referring to Jane Heal, professor of philosophy, University of Cambridge, that "it is very unlikely that we possess any general theory that allows us to decide which of the myriad beliefs we and other people have are relevant to consider in a particular situation. Our only option is to use our own cognitive capacities and to put ourselves imaginatively in their shoes in order to grasp their thoughts as their reasons". (Note 23) Not for the last time, we see the overlay and interaction of aesthetic possibilities (imagination) and mentation (cognitive capacities, thoughts as their reasons, beliefs), revolving around community experience and background resources (cultural habits, institutions, supra-individual facts, beliefs, situations). In the end, our aim, with the help of historical writers, is to effect joint action and communication by "putting ourselves in the shoes of others," helping us to fully apprehend the aesthetics ethic and associated historical apprehension at individual and community levels. 
Let's examine a few examples of intersubjective and community elements at play in historical writings. The narrative in Saul Friedländer's The Year's of Extermination is illuminating. The historiography is told almost entirely by way of the virtually unmediated, wholly personal points of view of those who lived and died during the Shoah, by way of diaries, letters and other personal records - a "microlevel" history as Friedländer calls it. (Note 24) Though this is foremost uniquely experiential and expedient access to historical occurrence, it also becomes a rich dialectic, with individual voices always conditioned by community encounter, such that attitudes, reactions, viewpoints expressions, illusions, rumors, interpretations, intuitions, beliefs, commitments and values are at once individual and collective, subjective and intersubjective, personal and communal. (Note 25)

The findings of a historical work built around the plaintive but uniquely informed "individual voice," (Note 26) given that such a voice is itself something of a combination of the factual and the fictional, make it such that they "are not subject to the usual rules of historical evidence," and "cannot be proven untruthful in the usual way that specific factual statements in an historical account might turn out to be false". (Note 27) Rather, this model is best judged by way of a more flexible and inclusive stable of "diverging emotions, tastes, intuitions, philosophies, and identities" (Note 28) - which is a view not only of the possibilities of fictionalized history, with its unique ways with "the rules of historical evidence," "specific factual statements" and a "flexible and inclusive stable" of meaning creation, but even more importantly is at one with Daniel Wickberg's histories of sensibilities as exemplars of how an aesthetics ethic can be employed in historical analysis. I will examine Wickberg's work, below.

Turning to a fictional example, Erich Maria Remarque (1898-1970) in his All Quiet on the Western Front evinced a vibrant community ethic in his matchless and deeply empathetic way. Speaking of his fellow soldiers, the novel's protagonist Paul Bäumer reflects,

At once a new warmth flows through me. These voices, these few quiet words, these footsteps in the trench behind me recall me at a bound from the terrible loneliness and fear of death by which I had been almost destroyed. They are more to me than life, these voices, they are more than motherliness and more than fear; they are the strongest, most comforting thing there is anywhere: they are the voices of my comrades.

I am no longer a shuddering speck of existence, alone in the darkness;- - I belong to them and they to me, we all share the same fear and the same life, we are nearer than lovers, in a simpler, harder way; I could bury my face in them, in these voices, these worlds that have saved me and will stand by me. (Note 29)

To turn to an example from non-fiction historiography, James M. McPherson, in Battle Cry of Freedom, highlights a "mutual salutation and farewell" that rings of solidarity in the most difficult conditions, during the surrender of the Confederate armies in April 1865:

First in line of march behind him General John B. Gordon was the Stonewall Brigade, five regiments containing 210 ragged survivors of four years of war. As Gordon approached at the head of these men with "his chin drooped to his breast, downhearted and dejected in appearance," Joshua L. Chamberlain gave a brief order, and a bugle call rang out. Instantly the Union soldiers shifted from order arms to carry arms, the salute of honor. Hearing the sound General Gordon looked up in surprise, and with sudden realization turned smartly to Chamberlain, dipped his sword in salute, and ordered his own men to carry arms. These enemies in many a bloody battle ended the war not with shame on one side and exultation on the other but with a soldier's "mutual salutation and farewell". (Note 30)

These historical passages sound the optimistic notes that seem to intuitively attend to community ethics, intersubjectivity and historicality as we have examined - but we should pause to note a dark reverse to these ideas. For we find in many histories not the brighter notes of community sounded just above, but views of solidarity, social context, norms and community gone wrong, and desperate efforts to right them. In short we find in much narrated history that the ethics and purposeful action we have examined so far can be blasted to pieces by pitiless historical incident and outcome. No doubt we find this in Holocaust histories, and it is also a central theme of James M. McPherson's Battle Cry of Freedom, with his examination of the internecine carnage that marked the American Civil War, when the deaths of large numbers of people from one municipality "could mean sudden calamity for family or neighborhood". (Note 31) As well, the war's tragic parricide is a theme of the book, with Robert E. Lee stating that "I cannot raise my hand against my birthplace, my home, my children," (Note 32) and McPherson also writing that the war in Kentucky was "literally a brothers" war. Four grandsons of Henry Clay fought for the Confederacy, and three others for the Union. One of Senator John J. Crittenden's sons became a general in the Union army and the other a general in the Confederate army. The Kentucky-born wife of the president of the United States had four brothers and three brothers-in-law fighting for the South". (Note 33) In a spectacular exemplification of these historical facts, Michael Shaara (1928-1988) in The Killer Angels, a 
novelization of the same period about which McPherson writes non-fiction, portrays the relationship of Generals Lewis Addison Armistead and Winfield Scott Hancock. The two had been bosom friends and fought together in the United States Army before southern secession pulled them apart, and they found themselves facing each other across the lines at the Battle of Gettysburg. Armistead blanched at the possibility that he would be required to fire on his dear mate. After General James Longstreet's loss at Little Round Top on July 2, and as the southerners are preparing for the next day's massed charge at the Union center, Armistead and Longstreet confer: "'You hear anything of Win Hancock?" Armistead asks "old Pete". Longstreet answers with darkly bemused resignation, "Ran into him today. He's over that way, a mile or so." (Note 34) As Armistead recalls the news three years before that the Union was breaking up, and the various officers were realizing they could end up antagonists, he continues of Hancock:

"Well, the man was a brother to me. You remember. Toward the end of the evening...it got rough. We all began, well, you know, there were a lot of tears. Well, I was crying, and I went up to Win and I took him by the shoulder and I said, 'Win, so help me, if I ever lift a hand against you, may God strike me dead.' I've not seen him since. I haven't been on the same field with him, thank God. It...troubles me to think on it. Can't leave the fight of course. But I think about it. I meant it as a vow, you see. You understand, Pete?" (Note 35)

Armistead and Hancock's relationship, though truthful and genuinely revealing of the tragic fratricide of the war, is not addressed by McPherson, and we are fortunate to have Shaara's truth-cum-fiction examination. (Note 36)

Another example from Remarque of the destruction of the very intersubjectivity that is a principal source of historicality and historical consciousness, and a superhuman effort to reconstruct it, is powerful. In his depiction of the encounter of Paul Bäumer and Gérard Duval in the trenches in World War I, Remarque orders a brilliant tableaux of everything we hope history will not become. As Paul sinks to the ground to protect himself from machine gun fire, another body leaps into the trench, and Paul strikes "madly home" at the man with his knife, immobilizing him. (Note 37) In his boiling wrath, he rages at the slumped, murmuring figure, "I want to stop his mouth, stuff it with earth, stab him again, he must be quiet, he is betraying me". (Note 38) He spends the night with the unconscious man, and in the morning when he sees he has opened his eyes, with "an extraordinary expression of flight," his humanity returns and he whispers to him, "No, no. I want to help you, Comrade, camerade, camerade, camerade." (Note 39) Paul laments that "This is the first man I have killed with my hands," and he tries to restore the injured man's status as a fellow human being, even noting that his eyes are "brown, his hair is black and a bit curly at the sides". (Note 40) Paul tries to enlarge and repair this battered intersubjectivity and thinks, "No doubt his wife still thinks of him," and then "Does she belong to me now? Perhaps by this act she becomes mine". (Note 41) He continues of the astonishingly thin line between constructive affinity and fearful loss, "I wish Kantorek was sitting here beside me. If my mother could see me ... if Kemmerich's leg had been six inches to the right; if Haie Westhus had bent his back three inches further forward-". (Note 42) Baumer finds photographs of the dying man's wife and a girl in his wallet and some letters, tries to decipher the French, and then enfolds himself in what he hopes can be a germinal beneficence: "This dead man is bound up with my life," he thinks, "therefore I must do everything, promise everything, in order to save myself; I swear blindly that I mean to live only for his sake and his family". (Note 43) In the somber denouement to this scene, Paul finds the man's name, and tries to renovate the now-ravaged life connections, fantasizing an intersubjective traversal and union: "I have killed the printer, Gérard Duval. I must be a printer". (Note 44) The grim consummation of experiences like this - and the reader no doubt knows they veritably saturate All Quiet on the Western Front-is that Bäumer and his fellows "are forlorn like children, and experienced like old men, we are crude and sorrowful and superficial - I believe we are lost". (Note 45)

History comes alive in Remarque's text, and here it speaks to us across fictional and non-fictional limits- "more vivid, more immersive than a work of history," as Marie-Laure Ryan has written. (Note 46) In penetrating and disturbing ways Remarque's reporting casts in a different light the above discussion of community, social processes, a given humanitarian "mission and duty," the imaginative placement of oneself in another's shoes, irreducible social practices, social contexts, forms of solidarity, shared action, and a now-seemingly vain "celebration of the life of a civilization". Such a dialog is no doubt necessary, for surely these are experiences we do not want to find ourselves "doomed to repeat". (Note 47)

In sum we see in the above examples common filaments of historical apprehension, meaning and interpretation running like threads through an "arras web" (to borrow from Hayden White) of fictional and non-fictional historical literatures, becoming, in light of Wolfgang Iser's (1926-2007) brilliant literary analysis, a true "product of interconnection," a "referential field" with "viewpoints switching between perspective segments". (Note 48) These filaments interweave within and without historical texts, with common voicings and analyses found first at textual levels, and from there into readers' worlds. 
To continue this discussion, I want to further link my "ethic" to the immediately-related discipline of "ethics" and the adjective "ethical" - in sum the adjuratory, affective admixture with all of its associated experience, deliberation, interaction, obligation, warrant, estimation, consent and evaluation. These factors and functions constitute the pith of the tenets, codes and customs used to formulate and condition advice and consent in the steering and orderly interaction of societies, as well as virtuous individual behavior, humanistic concern, and constructively principled conscious awareness. In short, the community/compositional model I am describing is a moral universe, with all of these factors the veritable "ethic" of my "aesthetics ethic". Hayden White sums up these transacting ideas this way:

The historical past is "ethical" in that its subject-matter (violence, loss, absence, the event, death) arouses in us the kinds of ambivalent feelings, about ourselves as well as about the "other," that appear in situations requiring choice and engagement in existentially determining ways. In order to deal with these kinds of events, which interest or should interest modern publics, appeal should be made to ethically rich traditions of literary expression. (Note 49)

As you read the following, keep in mind that without question the best historians and historical novelists are bound by a deep commitment to morals and ethical standards stemming from personal probity, professional standards, and, as we have discussed, performance of constructive inter-communicative tasks within the communities they are part of. Admittedly there can be quite a bit of freedom to bend these moral rules and ethical principles, but the essential truths remain, particularly for the "best" writers. As William Styron (1925-2006) wrote of The Confessions of Nat Turner "the reader may wish to draw a moral from this narrative"- and we may say the same of many another historical novel and factual history, as we shall see in the following. (Note 50)

At a high aesthetic level we can read these conceptions down into communal (historical) experience and communicative endeavor (the narrative, the aesthetic). Recall that the word moral simply means "custom," which I offer we may interpret as sets of decision-making practices and outcomes in human communities, as described just above. Hayden White again folds moral ingredients into the compote of historical narrative when he writes that "If every fully realized story, however we define that familiar but conceptually elusive entity, is a kind of allegory, points to a moral, or endows events, whether real or imaginary, with a significance that they do not possess as mere sequence, then it seems possible to conclude that every historical narrative has as its latent or manifest purpose the desire to moralize the events of which it treats". (Note 51) John Tosh, meanwhile, pragmatically reminds us that "historical interpretation is a matter of value judgments, moulded to a greater or lesser degree by moral and political attitudes," (Note 52) while William Cronon writes that "our historical narratives ... remain focused on a human struggle over values," and that "Within the field of our historical narratives we too-as narrators - are moral agents". (Note 53) Charles Maier, Leverett Saltonstall Professor of History, Harvard University, in a similar moral/narrative move linked to aesthetic contours of composition, comments on the vitally important narrative interpretation of moral and ethical issues when he posits the importance of "moral narratives" as overall organizing paradigms in historical writing. Such narratives importantly adumbrate, underlie and guide both historical reflection and apprehension, and moral decision-making and action in human communities (decision-making that is in large part informed by these historical narratives). Frank Ankersmit deepens this analysis when he notes that historians who attempt to "cut themselves out of the moral continuum" (by attempting to adhere to a disinterested positivist stance in their narrative interpretations) is to perform "a gesture of subjectivity of truly monstrous proportions". (Note 54) To sum up, in a moral/ethical and aesthetic milieu like that presented here, historical writers find they can "labor, thirsting for light upon the situation which confronts them," and then "emerge filled with joy when clarity is achieved, to experience the dissolution of the anxiety of the moral consciousness into the serenity of truth". (Note 55) If a bit high-flown, thoughts like these express what I think are the valuable philosophical and pragmatic foundations of the aesthetics ethic, ultimately yielding a constructive and applicable corpus of historical writing.

Like Jürgen Straub, Dewey called these varied elements a "storehouse of resources," (Note 56) while F.A. Olafson (emeritus professor of philosophy, University of California, San Diego) called this stockpile "a corpus of norms, interpretive principles, and background beliefs of a great variety of kind". (Note 57) Jürgen Habermas referred to "the lifeworld as represented by a culturally transmitted and linguistically organized stock of interpretative patterns," (Note 58) and Noël Bonneuil (Institut National des Études Démographiques and Ecole des Hautes Études en Sciences Sociales, Paris) writes with a dash of temporal apprehension of this decisional/historical/aesthetic universe that "people do make decisions under the pressure of present or anticipated constraints, and thus permanently modify their own history, their 'trajectory' in the space of possible 
states. ... Such decisions yield attainable states satisfactory to the group; technically speaking, they are the decisions, if they exist, that drive the group within the boundaries of the set of survival constraints". (Note 59) All of these factors and circumstances I think we may interpret as "customary" (moral) in human communities, and include them within the aesthetics ethic.

In terms of historical fiction, William Styron's The Confessions of Nat Turner is instructive. Styron's work is not only a brilliant reconstruction of historical reality in early nineteenth century slaveholding Virginia and the bloody slave rebellion led by Nat Turner, but also a sustained attack on the institution of slavery and the barbaric treatment and inhuman devaluation of black people in the United States. I think that the book's moral and ethical themes can be interpreted not only as windows onto the past, but also as decidedly hortatory, in terms of their applicability to the present and future (from the 1960s, when the book was published, during the height of civil rights activism in the U.S., and onward). In these ways, the book "reproduces the much more complex and ramifying totality with historical faithfulness". (Note 60) In Styron's work, Nat Turner's white owner Samuel Turner reviles slave-owning humanity, raging against their brutality and denouncing them as nothing more than vermin, and establishing primary anti-slavery and anti-degradation themes of the novel:

"Surely mankind has yet to be born. Surely this is true! For only something blind and uncomprehending could exist in such a mean conjunction with its own flesh, its own kind. How else account for such faltering, clumsy, hateful cruelty? Even the possums and the skunks know better! Even the weasels and the meadow mice have a natural regard for their own blood and kin. Only the insects are low enough to do the low things that people do-like those ants that swarm on poplars in the summertime, greedily husbanding little green aphids for the honeydew they secrete. Yes, it could be that mankind has yet to be born". (Note 61)

Genuine historical materials covering the slavery era in the United States-historiography, memoirs, letters and diaries, journalism accounts - have taken similarly denunciatory moral positions. Charles Ball wrote in his Slavery in the United States: a narrative of the life and adventures of Charles Ball, a black man that "the entire white population is leagued together by a common bond of the most sordid interest, in the torture and oppression of the poor descendents of Africa, (Note 62) and he described his life as "one long waste, barren desert, of cheerless, hopeless, lifeless slavery; to be varied only by the pangs of hunger, and the stings of the lash". (Note 63) Nat Turner in his confession referred to white people as "the Serpent," (Note 64) while in his narrative Frederick Douglass asked "why have these wicked men the power thus to trample upon our rights, and to insult our feelings?" (Note 65)

In McPherson's Battle Cry of Freedom - as often as not viewed as a straightforward, balanced, veritably "scientific" historical narrative - the immorality of slavery and the treatment of blacks, as well as other historical data, are also moralistically conveyed through carefully chosen diction and imagery: Slavery was a "cancer" (Note 66) in the U.S. South, the floundering southern economy functioned like "Alice in Wonderland," (Note 67) and the hellion avenger John Brown had "the glint of a Biblical warrior in his eye". (Note 68) McPherson writes how Harriet Beecher Stowe - who had "breathed the doctrinal air of sin, guilt, atonement, and salvation since childhood"- condemned slavery in her influential Uncle Tom's Cabin, but then he himself conjectures: "or perhaps it was God" who did so. (Note 69) This is colourful, aestheticized moralism at work in straight historiography - but this should not surprise us. McPherson even challenges the reader to come down on one side or the other of one of the ultimate moral questions of the Civil War when he asks in the conclusion of the book, "Was the liberation of four million slaves and the preservation of the Union worth the cost of more than 620,000 dead? That question too will probably never cease to be debated". (Note 70)

Another way that moralism is conveyed by historical writers in this area is a reverse of what we have seen, through the presentation of the arguments of pro-slavery advocates - arguments that we denounce for their ludicrous posturing, illogicality, and hateful bias. In The Battle Cry of Freedom, McPherson writes how pro-slavery defenders wrote and spoke of manifold "blessings" of slavery - it had "civilized African savages and provided them with cradle-to-grave security," (Note 71) relieved whites of menial labour of all kinds, stabilized necessary and admirable class and caste systems and created a refined upper class of Southern gentry who added much to American culture. Slavery had, in a word, done no less than created "a most safe and stable basis for free institutions in the world". (Note 72) To compare again to historical fiction, Styron put some of the uglier pro-slavery arguments in the mouths of characters in his novel, and we feel disgust with their odious chicanery. "My brother is as sentimental as an old she-hound," says Benjamin Turner after his brother's anti-slavery argument. (Note 73) "He believes slaves are capable of all kinds of improvement. That you can take a bunch of darkies and turn them into shop-owners and sea captains and opera impresarios and army generals and Christ knows what all. I say differently. I do not believe in beating a darky. I do not believe, either, in beating a dog or a horse. If you wish my belief ... my belief is that a darky is an animal with the brain of a human child and his 
only value is the work you can get out of him by intimidation, cajolery, and threat". (Note 74) Similarly, the nasty ruminations and justifications of slavery by Nat Turner's legal adviser, Thomas Gray, yield the same results, with Gray at one point listing a number of slaves captured after the Turner revolt who had not been hanged, then announcing the simon-pure propriety of southern society, and topping it off with a detestable boast: "Dad-burned mealy-mouthed abolitionists say we don't show justice. Well, we do. Justice! That's how come nigger slavery's going to last a thousand years". (Note 75) In a similar light, Styron presents other then-current arguments about these issues, as when Gray considers the "the meddlin' and pryin"" of non-violent Quakers "and other such moralistically dishonest detractors" who "so ignorantly decried" slavery's inherent "benevolence". (Note 76)

To continue, Styron condemns, by way of the voice of Nat Turner, the white people of Virginia, who were "reptilian in spirit," and who mete out to blacks "blistering toil and deprivation, slights and slurs and insults, beatings, chains, exile from beloved kin". (Note 77) In a deft narrative touch that allows his words to be read as either the thoughts of Nat Turner, or as the exposition of an omniscient narrator, Styron also wrote of "the white man's wiles, his duplicity, his greediness, and his ultimate depravity". (Note 78) Those needing confirmation about whether or not this is "history"-and not simply the made-up fantasies of an over-imaginative writer - may simply refer to the works of McPherson, Ball, Turner and Douglass.

In another example, Richard Hofstadter, in The American Political Tradition, poses a beautifully oblique and erudite moral examination and critique of the thought of the American founding fathers. In chapter 1, "The Founding Fathers: An Age of Realism," he observes that these political men could ambiguously be "starkly reactionary" on the one hand, but possess "a statesmanlike sense of moderation" on the other. (Note 79) More critically, Hofstadter notes that "From a humanistic standpoint there is a serious dilemma in the philosophy of the Fathers, which derives from their conception of man," which was contradictory in that "while they thought self-interest the most dangerous and unbrookable quality of man, they necessarily underwrote it". (Note 80 ) For the Founding Fathers, mercantilist to the core, their conception of the best state sought less to shape it in a humanistic or even particularly fair-minded way, but simply to "make it less murderous"-hardly a high-minded moral stance. (Note 81) Ultimately, and bringing the argument into the present day, "Modern humanistic thinkers who seek for a means by which society may transcend eternal conflict ... can expect no answer" in the philosophy of the Founding Fathers. (Note 82) I can just about see a Gore Vidal or a Norman Mailer going to town on complex ideas like these, and fashioning them into challenging, creatively re-imagined fictional interpretations of received history....

To pull my focus back a bit, I turn to Hans Robert Jauss, who skillfully links a moral/ethical imperative to aesthetics and associated communal and communicative conceptions, drawing my aesthetics ethic perhaps into his aesthetics of reception when he writes, "The relationship between literature and reader can actualize itself in the sensorial realm as an incitement to aesthetic perception as well as in the ethical realm as a summons to moral reflection". (Note 83) And finally, Frank Ankersmit commandingly writes of the ties that bind historical writers and their creations to their communities, their sensibilities, and deeper and wider moral and ethical obligations:

"L'histoire se fait avec des documents"-indeed, but also with historians. How historians relate to their own time, what are their innermost feelings and experiences, what have been the decisive facts in their own lives - these are all things that should not be distrusted and feared as threats to so-called historical subjectivity but cherished as historians' most crucial asset in their effort to penetrate the mysteries of the past. ... They are absolutely indispensable for historians' being open to the experience of the past, which is, in turn, the bridge to the past for both the historians and their readers. The historians' own sentiments, their convictions and feelings, provide them with the fertile ground on which historical experience can flourish. (Note 84)

As the battery of thinkers and writers cited above makes clear, moral and ethical stipulations evince the very structure and content of human interaction and historicity. These analyses I think substantiate my aesthetics ethic, and we can see how they deeply condition the very lifeblood coursing through historical texts, with such teeming ideas and comment showing that "our moral judgments are made within a conceptual framework which is itself the creation of history". (Note 85)

This discussion has constituted a deep and wide experiential and analytical channel, packed with complexity and the occasional tentative hypothesis and/or speculative theorizing. It is my hope, however, that thoughts like these confirm my view that the aesthetics ethic comprises historical experience, awareness and communication evinced in and by individuals and communities, with all of their embedded dependencies, obligations, interfaces and aesthetic senses. This is, to be sure, a lot more than wie es eigentlich gewesen. Our target in this analysis is a moving one, and rather than a linear analysis, our strategy is veritably a climbing spiral staircase by way of 
which we will make our way forward and higher. Yes, we may find ourselves a bit dizzy at times, but not I think vertiginous. With this said, I turn to a more specific and pragmatic examination of how community and intersubjective considerations and factors within the aesthetics ethic can enter into historical analysis and narrative, yielding more complete, accurate and constructive narratives of historical experience: Daniel Wickberg's Histories of Sensibilities.

\section{The Aesthetics Ethic and Histories of Sensibilities}

DANIEL WICKBERG'S FOCUS on the importance of "histories of sensibilities" provides, I believe, an ideal platform for historical writing in terms of key elements of my aesthetics ethic. Wickberg, associate professor of Historical Studies/History of Ideas at the University of Texas at Dallas, discusses and defines "sensibilities" as "modes of perception and feeling, the terms and forms in which objects were conceived, experienced, and represented in the past," as well as "ideas, emotions, beliefs, values". (Note 86) With thoughts like these in support of his ideas, Wickberg goes on to provide meat to his theoretical bones when he writes of the importance of recovering and relating history by way of individual and group sensibilities. These terms and ideas can be directly linked to the aesthetics ethic and the other ideas and analysis I have cited, above and going forward.

Wickberg's model suggests the importance of what E.H. Carr called "the historian's need of imaginative understanding of the minds of the people with whom he is dealing" (Note 87) - in short a proper and more complete, textured, varied and intricate picture of past historical experience (by way of "walking in their shoes"). Karsten Stueber, sounding exactly like Wickberg, writes that "in order to be able to grasp agents' thoughts as reasons for their actions we have to reenact their thoughts, beliefs, and desires in our own mind while being simultaneously appropriately sensitive to relevant differences between ourselves and the people whose actions we want to understand". (Note 88) Even further, historical writers' own sensibilities can be linked up to those of historical subjects and objects, yielding a transaction of varied points of view and characterizations, and ultimately bringing the past into view by way of a richly transgressive blend, which becomes "historians' most crucial asset in their effort of penetrate the mysteries of the past". (Note 89)

Wickberg's framework links back to the vagaries, complexities, subjunctivity and contingency of conscious lived experience within the aesthetics ethic, which are keys not only to historical apprehension, but are also experiential springs that skilled narrativists may be particularly apt at tapping into and fashioning into historical representation. Though to be sure both fictional and non-fictional writers can employ these ideas and methods, novels, even more than historiography, may be the optimal platform for presenting and representing the elaborate features of a people's sensibilities - as Doris Lessing wrote, "Novels give you a matrix of emotions, give you the flavour of a time in a way formal history cannot". (Note 90) To be sure, human sensibilities, mentalities, intellection and consciousness are not easily accessible or crystal clear "sources" with which to interpret historical experience, and are "not organized in archives and conveniently visible for research purposes". (Note 91) Interestingly, in this respect these mindful factors may hearken to the "absences" that theory tells us pepper the past - and nobody is cowed by these factors, and in fact in terms of history in all its heterogeneous glory, they may, if at times ambiguously, provide something of a high road toward historical understanding. In any event, a people's sensibilities seem to ideally comprise the important points and factors we have been examining within the aesthetics ethic, and they become "a concept that lets us dig beneath the social actions and apparent content of sources to the ground upon which those sources stand: the emotional, intellectual, aesthetic, and moral dispositions of the persons who created them". (Note 92)

Modern historians have recognized the value of an approach like Wickberg's. Perry Miller (1905-1963), in his masterful The New England Mind: The Seventeenth Century, emphasized that he was "seeking to delineate the inner core of Puritan sensibility," as well as the importance of describing "the temperamental bias behind Puritan thought". (Note 93) Kenneth Stampp (1912-2009) noted in The Peculiar Institution that "since there are few reliable records of what went on in the minds of slaves, one can only infer their thoughts and feelings from their behavior, that of their masters, and the logic of their situation". (Note 94) Paul Cohen in his History in Three Keys: The Boxers as Event, Experience, and Myth wrote that part 2 of his tome would "delve into certain facets of the experiential context" of the historical subjects, the "thought, feelings, and behavior of the immediate participants," "the motivational consciousness of the experiencer" of past events, and in turn the way they "made sense of world". (Note 95) We are all, Cohen writes, "experiencers ourselves, not of the past but of $a$ past," and thus we can see the importance of individual experience merging into what Cohen calls "coalesced" historical intersubjectivity. (Note 96)

Examples like these show that Wickberg is not alone in his thinking. Paul Ricoeur wrote of a "complex interplay of superimposed intentionalities" in history and historical writing, (Note 97) and Lawrence Stone has written that 
historiography is now focusing on "man in circumstances" as opposed to "the circumstances surrounding man". (Note 98) Stone continues that historiography has seen a "growth of interest in feelings, emotions, behavior patterns values, and states of mind" of peoples of the past, and adds that we need "to discover what was going on inside people's heads in the past, and what it was like to live in the past". (Note 99) Stone concludes with an important point in terms of our examination, noting that such questions "inevitably lead back to the use of narrative". (Note 100) In a related point, Peter Burke (Life Fellow, Emeritus Professor of Cultural History, Emmanuel College) highlights the "micronarrative," the "telling of a story about ordinary people in their local setting" (Note 101) - a model that has become critical in modern historical writing.

It is through these varied and delightfully intricate channels that "more and more people emerge into social and political consciousness, become aware of their respective groups as historical entities having a past and a future, and enter fully into history". (Note 102) Thus, the genuine experiences of past peoples can be located, examined and portrayed in these histories, with they envisioning and apprehending their lives within greater unfolding historical movement and change, beginning in the past, proceeding into the present, and portending future experience - in sum the essence of historical temporality and consciousness.

Wickberg's valuable analysis provides a key understanding of history that links individual and community consciousness and experience as they interact and play their roles in the depth and breadth of historical experience, lived and narrated. I emphasize that these ideas go a long way toward showing us a best "thick" way to both show and tell history in all its profound, associative, synthetic and delightfully piebald abundance. My own approach may be less "history of sensibilities" than "history as sensibility," with the various terms - emotion, intellect, morality, ideas, beliefs, values, points of view, feelings, dispositions, perception, confidences, assumptions - and their associated behaviors, responses, interpretations, processes, undertakings - emerging out of and then back into my aesthetics ethic, and then in turn linking to human conscious experience as a main conduit in the flow of historical experience, understanding and writing.

The intricacies I have examined comprise an almost endlessly granular, variegated, delightfully indeterminate human existence, an elaborate triptych, comprising that "corpus of norms" referred to by Olafson, in sum an "element of tradition," which "any society builds up over time and which it brings to new situations that arise and which are interpreted for purposes of action in terms of the affinities they show to one or another of the categories that are the precipitate of past experience". (Note 103) Such dimensions are the true marrow of lived historical experience, an "extended historicity" that is "of the greatest importance for a historian," and which seem to burst at the seams with narrative possibilities. (Note 104) Benedetto Croce adds depth and complexity to these descriptions, capturing and describing the origins and functions of our richly substantive and wholesome historical culture (culture understood as "cultivation of living material in prepared nutrient media" indeed seems to be the ideal word to use), (Note 105) when he, again temporally, writes:

Historical culture has for its object the keeping alive of the consciousness which human society has of its own past, that is, of its present, that is, of itself, and to furnish it with what is always required in the choice of the paths it is to follow, and to keep in readiness for it whatever may be useful in this way, in the future. (Note 106)

All of the above description, explication and analysis within the bounds of the proposed aesthetics ethic are the veritable source and ground of both fictional and non-fictional historical narrative. The model we have discussed is a living, breathing rhizome that constitutes a social/community framework with virtually universal aesthetic factors evincing the structural support and causeways of significance of a human "aesthetic gaze". Historical writers function in this environment in important ways, accessing manifold aesthetic/artful/compositional methods and features to be employed in their narratives. It is indeed largely for these reasons that, as Ankersmit has written, "the history of historical writing is ... in the final analysis, a chapter in the book of the history of aesthetics". (Note 107) And I think that these channels of mood, feeling and experience expand outward magnificently, and may be the source of Ankersmit's experienced historical "sublimity". Ankersmit has informed us in this light that "moods and feelings" are the veritable "locus of" and "have a natural affinity with" historical experience, and that "one might well say that sublime historical experience preferably makes itself felt in these moods and feelings". (Note 108) All of this must be the source of what Huizinga, in the same vein, called "the grace of historical experience". (Note 109)

\section{Conclusion}

IN TERMS OF THE aesthetics ethic, I hope I have effectively illustrated the important ways that our subjects condition historical apprehension, and shown how aesthetic experience can open our eyes to new depths in historical consciousness and composition. Some will accuse me of totalizing, but I think not, and I hope that our examination has highlighted not a few aporias, incertitudes and cognitive dissonances, some byways, shortcuts, 
roundabouts and cul de sacs, a few useful on-ramps and off-ramps, with all of this complexity and retroflexion suggesting that ours is anything but a simple, straightforward model. In any case, and whatever the neatness of my model, I hope that I have shown some of the narrative essences, phenomenological sources and common structural members common to fictional and non-fictional history writing, the indices of which lead us into more varied areas of experience, communication and interaction, and enable us to apprehend in more accurate and integrated ways aggregate narrative formations of history and narrative. Perhaps, in this world, the aesthetic in life is "no intruder from without," but is virtually a "clarified and intensified development of traits that belong to every normally complete experience". (Note 110)

Ours has been a complex world, a world of perhaps infinite possibility, in which history happens, and out of which history is written, a contested zone between science and art, objectivity and subjectivity, reality and... irreality (to borrow from Paul Ricoeur). To conclude, such breadth leads us to Wolfgang Iser, whose richly inventive analysis captures the contours of our discussion at a wonderfully elevated level. He writes of transacting fictional and non-fictional histories with interwoven filaments of meaning and configuration, speaking with a common interpretive voice, found first at textual levels, and from there into responsive "reading moments". (Note 111) Iser seems almost to have forecast my aesthetics ethic when he wrote the following - but first I should give the reader some background. In his reference to "segments" in the following, Iser had in mind his textual blanks, which he had modified into "vacancies," which are "nonthematic segments within the referential field of the wandering viewpoint". (Note 112) These vacancies are "important guiding devices for building up the aesthetic object because they condition the reader's view of the new theme, which in turn conditions his view of the previous themes". (Note 113) This said, Iser's text continues, I hope redolently of the attributes of my aesthetics ethic, that this environment and communicative universe "enables the reader to combine segments into a field by reciprocal modification, to form positions from those fields, and then to adapt each position to its successor and predecessors in a process that ultimately transforms the textual perspectives, through a whole range of alternating themes and background relationships, into the aesthetic object of the text". (Note 114) I thank readers for their attention, and to reverse our focus, I wish them wonderful futures.

\section{References}

Ankersmit, F.R. (2004, December). The Ethics of History: From the Double Binds of (Moral) Meaning to Experience. History and Theory, Theme Issue 43, 84-102. http://dx.doi.org/10.1111/j.1468-2303.2004.00299.x

-. (2005). Sublime Historical Experience. Stanford: Stanford UP.

Ball, Charles. Slavery in the United States: a narrative of the life and adventures of Charles Ball, a black man. Lewistown, Pa., 1836. The Making of the Modern World. Gale 2008. Gale, Cengage Learning. National Chengchi U. 11 July 2008 http://0-galenet.galegroup.com.jenda.lib.nccu.edu.tw:80/servlet/ MOME$? \mathrm{af}=\mathrm{RN} \& \mathrm{ae}=\mathrm{U} 3605500695 \& \operatorname{srch} \mathrm{tp}=\mathrm{a} \& \mathrm{ste}=14$

Bonneuil, Noël. (2001, December). History, Differential Inclusions, and Narrative. Wesleyen University, History and Theory, Theme Issue, 40, 101-115. http://dx.doi.org/10.1111/0018-2656.00184

Burke, Peter. (2001). History of Events and the Revival of Narrative. In Geoffrey Roberts (Ed.), The History and Narrative Reader (pp. 305-317). London and New York: Routledge.

Carr, Edward Hallett. (1961, January-March). What is History? The George Macaulay Trevelyan Ledtures delivered in the University of Cambridge.

Cohen, Paul. (1997). History in Three Keys: The Boxers as Event, Experience, and Myth. New York: Columbia UP.

Croce, Benedetto. (1941, 1949, 1962). History as the Story of Liberty, Trans. by Sylvia Sprigge. Taipei: Rainbow Bridge Book Co.

Cronon, William. (2001). A Place for Stories: Nature, history and narrative. In Geoffrey Roberts (Ed.), The History and Narrative Reader (pp. 409-434). London and New York: Routledge.

Dewey, John. (1934). Art as Experience. New York: Minton, Balch \& Company.

Douglass, Frederick. (1987). My Bondage and My Freedom. Ed. and with an introduction by William L. Andrews.

Ellison, Ralph, William Styron, Robert Penn Warren, \& C. Vann Woodward. (1969, Spring). The Uses of History in Fiction. Southern Literary Journal, 1, 57-90. Retrieved from $\mathrm{http}: /$ books.google.com/books?id=L0lb8WoLRDkC\&printsec $=$ frontcover $\# \mathrm{v}=$ onepage $\& \mathrm{q}=\& \mathrm{f}=$ false 
Goldhagen, Daniel Jonah. (1998). Hitler's Willing Executioners: Ordinary Germans and the Holocaust. New York: Alfred A. Knopf.

Gray, Thomas R., Turner, Nat, \& Royster, Paul. (Depositor). The Confessions of Nat Turner (1831), Libraries at University of Nebraska-Lincoln, Electronic Texts in American Studies, 2007. Retrieved from http://digitalcommons.unl.edu/etas/15

Habermas, Jürgen. (1987, 1989). The Theory of Communicative Action, Volume 2: Lifeworld and System: A Critique of Functionalist Reason, Trans. By Thomas McCarthy. Cambridge, UK: Polity Press.

Hofstadter, Richard. (1948). The American Political Tradition and the Men Who Made It. New York: Vintage Books.

Huizinga, Johan. (1956, 1970). Historical Conceptualization. In Fritz Stern (Ed.), The Varieties of History: From Voltaire to the Present. London and Basingstoke: MacMillan and Co. Ltd.

Iser, Wolfgang. (1989). Interaction between Text and Reader. In Prospecting: From Reader Response to Literary Anthropology (pp. 31-41). Baltimore: The Johns Hopkins UP.

-. (2001). Literary History as a Challenge to Literary Theory. In Vincent B. Leitch (Ed.), The Norton Anthology of Theory and Criticism (pp. 1150-1564). New York: W.W. Norton \& Company.

Kansteiner, Wulf. (2009, May). Success, Truth, and Modernism in Holocaust Historiography: Reading Saul Friedländer Thirty-Five Years after the Publication of Metahistory. History and Theory, Theme Issue, 47, 25-53. http://dx.doi.org/10.1111/j.1468-2303.2009.00497.x

Lessing, Doris. (1994). The Golden Notebook. New York: HarperPerennial.

-. (1988). Battle Cry of Freedom: The Civil War Era. New York, Oxford: Oxford UP.

Merriam-Webster's Collegiate Dictionary (10 ${ }^{\text {th }}$ ed.). (1993). Springfield, Mass.: Merriam-Webster, Inc..

Miller, Perry. The New England Mind: The Seventeenth Century. Cambridge, Mass., London: Harvard UP. Copyright 1939 by Perry Miller, copyright 1954 by the president and fellows of Harvard College, copyright 1982 by Elizabeth W. Miller.

-. (2001). The Dialectic of Action. In Geoffrey Roberts (Ed.). The History and Narrative Reader (pp. 71-106). London and New York: Routledge.

Remarque, Erich Maria. (1929). All Quiet on the Western Front. Boston: Little, Brown, and Company.

-. (1983). Time and Narrative, vols. 1, 2, 3. Translated by Kathleen McLaughlin and David Pellauer. Chicago and London: $\mathrm{U}$ of Chicago P.

Scholes, Robert, \& Robert Kellogg. (1975). The Nature of Narrative. Oxford: Oxford UP.

Shaara, Michael. (1974). The Killer Angels. New York: Ballantine Books.

Stampp, Kenneth. (1967). The Peculiar Institution: Slavery in the Ante-Bellum South. New York: Alfred A. Knopf.

Stone, Lawrence. (2001). The Revival of Narrative: Reflections on a new old history. In Geoffrey Roberts (Ed.), The History and Narrative Reader (pp. 281-298). London and New York: Routledge.

Straub, Jürgen. (2005). Narration, Identity, and Historical Consciousness. New York: Berghan Books.

Stueber, Karsten R. (2008, February). Reasons, Generalizations, Empathy, and Narratives: The Epistemic Structure of Action Explanation. History and Theory, 47, 31-43. http://dx.doi.org/10.1111/j.1468-2303.2008.00434.x

Styron, William. (1966,1967). The Confessions of Nat Turner. A Signet Book published by the New American Library, New York. Copyright, by William Styron.

Styron, William. (1993). The Confessions of Nat Turner (25 ${ }^{\text {th }}$ Anniversary ed.). New York: Vintage International, Vintage Books.

Topolski, Jerzy. (1999, May). The Role of Logic and Aesthetics in Constructing Narrative Wholes in Historiography. History and Theory, 38(2), 198-210. http://dx.doi.org/10.1111/0018-2656.00086

Tosh, John. (1984, 1991). The Pursuit of History: Aims, methods and new directions in the study of modern history. London and New York: Longman.

Vidal, Gore. (1984). Lincoln: A Novel. New York: Ballantine Books. 
- (1986). The Value of Narrativity in the Representation of Reality. In The Content of the Form. Baltimore and London: The Johns Hopkins UP, pp. 1-25.

-. (2005, October). The Public Relevance of Historical Studies: A Reply to Dirk Moses. History and Theory, 44, 333-338. http://dx.doi.org/10.1111/j.1468-2303.2005.00327.x

Wickberg, Daniel. (2007, June). What Is the History of Sensibilities? On Cultural Histories, Old and New. The American Historical Review, 112(3), 661-684. http://dx.doi.org/10.1086/ahr.112.3.661

\section{Notes}

Note 1. Robert Scholes, Robert Kellogg, The Nature of Narrative (Oxford: Oxford UP, 1975), 82.

As noted, the sum of my arguments extends beyond the positions that will be examined in this paper, and will be taken up in future analyses. For example, details of narrative human consciousness, frequently referred to in this paper, are not fully addressed. Additionally, specific aesthetic contours will not be examined in detail. These contours include: dense temporality; subject-, object- and intersubjectivity; intertextuality; narrative form and fettle; semantic/syntactic complexity; historical, moral, argumentative and aesthetic rhetoric; contingency and modality; the effort toward becoming; the function and results of aesthetic selection during composition; and the fluid construction and apprehension of truth in historical narrative. Here my focus will be limited, and I will endeavor to explain the aesthetics ethic, proper, as completely as possible.

Note 2. Johan Huizinga, "Historical Conceptualization," in The Varieties of History: From Voltaire to the Present, edited, selected and introduced by Fritz Stern. (London and Basingstoke: MacMillan and Co. Ltd. Copyright The World Publishing Company, 1956, 1970), 291.

Note 3. Ibid., 298.

Note 4. Ibid., 299, 300.

Note 5. F.R. Ankersmit, Sublime Historical Experience (Palo Alto: Stanford University Press, 2005), 96, emphasis in original.

Note 6. Jürgen Straub, Narration, Identity, and Historical Consciousness (New York: Berghan Books, 2005), 52.

Note 7. The important term "transaction" is from John Dewey (1859-1952) and Arthur F. Bentley (1870-1957) in their Knowing and the Known (Boston: Beacon Press, 1949). Transactional analysis for Dewey and Bentley allows for "the seeing together, when research requires it, of what before had been seen in separations and held severally apart" (112). The two philosophers wrote that "The transactional is in fact that point of view which systematically proceeds upon the ground that knowing is co-operative and as such is integral with communication. By its own processes it is allied with the postulational. It demands that statements be made as descriptions of events in terms of durations in time and areas in space" (vi).

Note 8. Daniel Jonah Goldhagen, Hitler's Willing Executioners: Ordinary Germans and the Holocaust (New York: Alfred A. Knopf, 1998), 153, 155, 186, 278, 279, 280.

Note 9. Ibid., 339.

Note 10. Gore Vidal, Lincoln: A Novel (New York: Ballantine Books, 1984), Afterword.

Note 11. William Styron, The Confessions of Nat Turner (New York: Vintage International Edition, 1993), 445.

Note 12. Naysayers will say that the answers and interpretations constructed by historical novelists are not definitive, and of course this is true--as it is true with the work of historians (a glance at how many historians have been accused of misrepresenting the facts, or getting the data wrong, attests to this). Such conditions are well understood by sophisticated readers, who know that in any historical writing the accuracy of information and the credibility of interpretations must be weighed, examined and judged. Not for the last time do we encounter the same strictures and requirements in historiography and historical novelization.

Note 13. Jerzy Topolski, "The Role of Logic and Aesthetics in Constructing Narrative Wholes in Historiography," History and Theory, Vol. 38, No. 2 (May, 1999), pp. 198-210. (c) Wesleyan University, 203.

Note 14. John Dewey, Art as Experience (New York: Minton, Balch \& Company. Copyright, 1934), 249.

Note 15. Ibid., 23.

Note 16. Ibid., 104.

Note 17. Ibid., 185, 14, 22. 
Note 18. Ibid., 326, 332.

Note 19. Topolski, "The Role of Logic," 206.

Note 20. William Cronon, "A Place for Stories: Nature, history and narrative," in The History and Narrative Reader, 409-434.. Ed. by Geoffrey Roberts, (London and New York: Routledge, 2001), 429.

Note 21. Paul Ricoeur, Time and Narrative, vol. 3, trans. by Kathleen McLaughlin and David Pellauer, (Chicago and London: U of Chicago P, 1983), 186.

Note 22. Karsten R. Stueber, "Reasons, Generalizations, Empathy, and Narratives: The Epistemic Structure of Action Explanation," History and Theory 47 February 2008, 31-43. (C) Wesleyan University, 31.

Note 23. Ibid., 36.

Note 24. Friedländer, ibid., xxiv.

Note 25. Ibid., xxv and passim.

Note 26. Ibid., xxvi.

Note 27. Wulf Kansteiner, "Success, Truth, and Modernism in Holocaust Historiography: Reading Saul Friedländer Thirty-Five Years After the Publication of Metahistory," History and Theory, Theme Issue 47 (May 2009), 25-53. (C) Wesleyan University 2009, 49.

Note 28. Ibid., 49.

Note 29. Erich Maria Remarque, All Quiet on the Western Front (Boston: Little, Brown, and Company, 1929), 215.

Note 30. James McPherson, Battle Cry of Freedom: The Civil War Era (New York, Oxford: Oxford UP, 1988), 850.

Note 31. Ibid., 326.

Note 32. Ibid., 281.

Note 33. Ibid., 297.

Note 34. Michael Shaara, The Killer Angels (New York: Ballantine Books, 1974), 257.

Note 35. Ibid., 258.

Note 36. Armistead was seriously wounded during Pickett's charge the following day, and died later in a Union battlefield hospital. Hancock visited his friend before he died. This historical incident is not fictionalized by Shaara.

Note 37. Remarque, Ibid., 219.

Note 38. Ibid., 219.

Note 39. Ibid., 222, 223.

Note 40. Ibid., 224, 225.

Note 41. Ibid., 225.

Note 42. Ibid., 225-226.

Note 43. Ibid., 228. Bäumer's promise reminds me of Armistead's vow to Hancock.

Note 44. Ibid., 228.

Note 45. Ibid., 123.

Note 46. Ryan is Scholar in Residence, University of Colorado, Boulder. This quote is from personal correspondence with her, 21 October 2009.

Note 47. In this way the above plot lines become useful and advantageous. By showing the symptoms of what we do not want to suffer, they may become a bitter antidote to the disease ("hair of the dog that bit you"), and point toward constructive community and affinity. Additionally, however, we could look at these ideas from another perspective, and rather than historical writers who report the erosion of constructive historical intersubjectivity and community ethics, we could examine those who effect such erosion. I mean here historical writers such as those who deny the Holocaust, or distort and revise history through lenses of extremist, inhumane and antagonistic political, cultural or ethical views. 
Note 48. Wolfgang Iser, "Interaction between Text and Reader," in Prospecting: From Reader Response to Literary Anthropology, 31-41, (Baltimore: The Johns Hopkins UP, 1989), 35, 36, 37.

Note 49. "The Public Relevance of Historical Studies: A Reply to Dirk Moses," History and Theory 44 (October 2005), 333-338. (C) Wesleyan University, 338.

Note 50. William Styron, The Confessions of Nat Turner (New York: New American Library, a Signet Book). Copyright, 1966, 1967 by William Styron. Quote from Author's Note, emphasis added.

Note 51. "The Value of Narrativity in the Representation of Reality," in The Content of the Form, 1-25, (Baltimore and London: The Johns Hopkins UP, 1986), 14.

Note 52. John Tosh, The Pursuit of History: Aims, methods and new directions in the study of modern history (London and New York: Longman, 1984, 1991), 44.

Note 53. Cronon, ibid., 426, 427.

Note 54. F.R. Ankersmit, "The Ethics of History: From the Double Binds of (Moral) Meaning to Experience". History and Theory, Theme Issue 43 (December 2004), 84-102. (c) Wesleyan University, 87.

Note 55. Paraphrase of Benedetto Croce, History as the Story of Liberty, trans. by Sylvia Sprigge, (Taipei: Rainbow Bridge Book Co., 1941, 1949, 1962), 184.

Note 56. Dewey, Art as Experience 17.

Note 57. Frederick A. Olafson, The Dialectic of Human Action," in The History and Narrative Reader, 71-106, edited by Geoffrey Roberts, (London and New York: Routledge, 2001), 95.

Note 58. The Theory of Communicative Action, Volume 2: Lifeworld and System: A Critique of Functionalist Reason, trans. by Thomas McCarthy, (Cambridge, UK: Polity Press, 1987, 1989), 124 and passim.

Note 59. "History, Differential Inclusions, and Narrative". History and Theory, Theme Issue 40 (December 2001), 101-115, (C) Wesleyan University, 105.

Note 60. Gyorgy Lukacs qtd. in Ralph Ellison, William Styron, Robert Penn Warren, C. Vann Woodward, “The Uses of History in Fiction," 57-90, Southern Literary Journal, 1 (Spring 1969), 151. Located on the WWW at $<\mathrm{http} / /$ books.google.com/books?id=L0lb8WoLRDkC\&printsec=frontcover\#v=onepage\&q=\&f=false $>$

Note 61. William Styron, The Confessions of Nat Turner. A Signet Book published by the New American Library, New York. Copyright, 1966, 1967 by William Styron, 216.

Note 62. Charles Ball, Slavery in the United States: a narrative of the life and adventures of Charles Ball, a black man. Lewistown, Pa., 1836, 1. Located on the WWW at $<$ http://0-galenet.galegroup.com.jenda.lib.nccu.edu.tw/servlet/MOME?dd=0\&af=RN\&locID=twnsc012\&srchtp= $\mathrm{a} \& \mathrm{c}=1 \& \mathrm{ste}=11 \& \mathrm{~d} 4=0.33 \& \mathrm{stp}=$ Author $\& \mathrm{dc}=\mathrm{flc} \& \mathrm{docNum}=\mathrm{U} 105500675 \& \mathrm{ae}=\mathrm{U} 105500675 \& \mathrm{tiPG}=1 \& \mathrm{an}=190102$ $75200100>$

Note 63. Ibid., 111.

Note 64. Thomas R., Gray, Turner, Nat, Royster, Paul (Depositor). The Confessions of Nat Turner (1831), Libraries at University of Nebraska-Lincoln, Electronic Texts in American Studies, 2007, 11. Located on the WWW at $<$ http://Digitalcommons.Unl.Edu/Etas/15>

Note 65. Frederick Douglass, My Bondage and My Freedom, edited and with an introduction by William L. Andrews. (C) 1987 by the Board of Trustees of the University of Illinois, 216.

Note 66. McPherson, Battle Cry of Freedom, 127.

Note 67. Ibid., 95.

Note 68. Ibid., 84.

Note 69. Ibid., 88, 89.

Note 70. Ibid., 854.

Note 71. Ibid., 56.

Note 72. Ibid. 56.

Note 73. Styron, The Confessions of Nat Turner, 161.

Note 74. Ibid., 161-162. 
Note 75. Ibid., 37.

Note 76. Ibid., 118, 93, 93.

Note 77. Ibid., 293.

Note 78. Ibid., 249.

Note 79. Richard Hofstadter, The American Political Tradition and the Men Who Made It (New York: Vintage Books, 1948), 15.

Note 80. Ibid., 16, 16.

Note 81. Ibid., 16.

Note 82. Ibid., 16-17.

Note 83. Hans Robert Jauss, "Literary History as a Challenge to Literary Theory," in The Norton Anthology of Theory and Criticism, Vincent B. Leitch, General Editor, 1150-1564, (New York: W.W. Norton \& Company, 2001), 1564.

Note 84. Ankersmit, Sublime Historical Experience, 191, emphasis in original. Ankersmit's reflections on "The historians' own sentiments, their convictions and feelings" point us toward Daniel Wickberg's histories of sensibilities, to be examined below.

Note 85. Edward Hallett Carr, What is History? The George Macaulay Trevelyan Lectures delivered in the University of Cambridge, January-March 1961. (c) Edward Hallett Carr, 76.

Note 86. Daniel Wickberg, "What Is the History of Sensibilities? On Cultural Histories, Old and New," 661-684, The American Historical Review, Vol. 112, Num. 3, June 2007, 662, 670.

Note 87. Ibid., 18.

Note 88. Ibid., 36.

Note 89. Ankersmit, Sublime Historical Experience, 191.

Note 90. Doris Lessing, The Golden Notebook (New York: HarperPerennial, 1994), x.

Note 91. Wickberg, "What Is the History of Sensibilities?”, 669.

Note 92. Ibid., 669.

Note 93. Miller's thoughts remind me of Goldhagen's modal/contingent diction describing history, noted above. Perry Miller, The New England Mind: The Seventeenth Century (Cambridge, Mass., London: Harvard University Press), copyright 1939 by Perry Miller, copyright 1954 by the president and fellows of Harvard College, copyright 1982 by Elizabeth W. Miller, 6 .

Note 94. Kenneth Stampp, The Peculiar Institution: Slavery in the Ante-Bellum South (New York: Alfred A. Knopf, 1967), copyright 1956 by Kenneth M. Stampp, 88.

Note 95. Paul Cohen, History in Three Keys: The Boxers as Event, Experience, and Myth (New York: Columbia University Press, 1997), xiv, xiv, 64, xiv.

Note 96. Ibid., 65.

Note 97. I liberally borrow from Ricoeur Time and Narrative Vol. 3, 36.

Note 98. Lawrence Stone, "The Revival of Narrative: Reflections on a new old history," in The History and Narrative Reader, 281-298, edited by Geoffrey Roberts, (London and New York: Routledge, 2001), 296.

Note 99. Ibid., 289, 289, emphasis added.

Note 100. Ibid., 289.

Note 101. Peter Burke, "History of Events and the Revival of Narrative," in The History and Narrative Reader, 305-317, edited by Geoffrey Roberts, (London and New York: Routledge, 2001), 311.

Note 102. Ibid., 144.

Note 103. Olafson, "The Dialectic of Human Action," 95.

Note 104. Both Olafson, "The Dialectic of Human Action," 95.

Note 105. Merriam-Webster's Collegiate Dictionary, Tenth Edition, Springfield, Mass.: Merriam-Webster, Inc., 1993. 
Note 106. Benedetto Croce, History as the Story of Liberty, trans. by Sylvia Sprigge, (Taipei: Rainbow Bridge Book Co., 1941, 1949, 1962), 199.

Note 107. Ankersmit, Sublime Historical Experience, 139.

Note 108. Ibid., 306, 308.

Note 109. Qtd. in Ankersmit Sublime Historical Experience, 67.

Note 110. Dewey, Art as Experience, 46.

Note 111. From Iser, "Interaction between Text and Reader," 36.

Note 112. Ibid., 37.

Note 113. Ibid., 37.

Note 114. Ibid., 37.

\section{Copyrights}

Copyright for this article is retained by the author(s), with first publication rights granted to the journal.

This is an open-access article distributed under the terms and conditions of the Creative Commons Attribution license (http://creativecommons.org/licenses/by/4.0/). 